\title{
Perception and Practice of People about Unani Medicine attending National Arogya Fair, Visakhapatnam, Andhra Pradesh
}

\author{
Abdul Raheem', Tamanna Nazli², Jugal Kishore ${ }^{3}$, Heena $^{4}$, Munawwar H Kazmi $^{5}$, \\ Syed Khadeerunisa $^{6}$, Ahmed Minhajuddin ${ }^{7}$, Syed Gulnawaz Ahmad ${ }^{8}$, Ghazala Javed ${ }^{9}$ \\ ${ }^{1,9}$ Research Officer and Scientist-4, ${ }^{2}$ Research officer, CCRUM, Headquarters, New Delhi, India. \\ ${ }^{3}$ Director Professor \& Head Community Medicine, ${ }^{4}$ Statistician, VMMC \& Safdarjung Hospital, New Delhi, India. \\ ${ }^{5}$ Deputy Director, ${ }^{6}$ Assistant Director (U), ${ }^{7,8}$ Research officer, Scientist-3, NRIUMSD, Hyderabad, Telangana, India. \\ DOI: https://doi.org/10.24321/2394.6547.202004
}

$\begin{array}{lllllll} & \mathbf{N} & \mathbf{F} & \mathbf{O}\end{array}$

Corresponding Author:

Tamanna Nazli, CCRUM, Headquarters, New Delhi, India.

E-mail Id:

tamanna.ccrum@gmail.com

Orcid Id:

https://orcid.org/0000-0003-4517-3485

How to cite this article:

Raheem A, Nazli T, Kishore J, Heena, Kazmi MH, Khadeerunisa S, Minhajuddin A et al. Perception and practice of People about Unani Medicine attending National Arogya Fair, Visakhapatnam, Andhra Pradesh. J Adv Res Ayur Yoga Unani Sidd Homeo 2020; 7(1\&2): 16-24.

Date of Submission: 2020-06-03

Date of Acceptance: 2020-06-28

\section{$\begin{array}{llllllll}\mathbf{A} & \mathbf{B} & \mathbf{S} & \mathbf{T} & \mathbf{R} & \mathbf{A} & \mathbf{C} & \mathbf{T}\end{array}$}

Background: Over the last few decades traditional medicine has gained worldwide acceptance. Awareness about Unani medicine has an important role in providing health education, prevention and management of diseases. However, literature search revealed that very few published data enlightening about Unani system of medicine are available.

Objectives: To assess the perception, practice and the extent of use of Unani system of medicine among the general public attending National 'Arogya Fair' 2017 held in Visakhapatnam, Andhra Pradesh.

Materials and Methods: A cross sectional, observational descriptive survey was conducted using pretested, predesigned structured questionnaire to assess the perception and practice regarding Unani system of medicine of sample of 1149 visitors attending the free health clinic at Central Council for Research in Unani Medicine (CCRUM) stall in the National 'Arogya Fair' held in Visakhapatnam, Andhra Pradesh between September 8-11, 2017.

Result: Out of 1149 subjects $60.05 \%$ were males and $39.95 \%$ were females with mean age $36.78 \pm 10.33$ years ranged between 13 to 82 years of age. The awareness level about Unani system of medicine was good, 1016 (88.42\%) respondents have heard or were aware of Unani system of medicine, of these respondents, only 480 (41.78\%) respondents have taken Unani medicines in the past for various problems, 133 (11.58\%) subjects had never heard about Unani system of medicine. Majority of the patients believed that Unani medicine had No side effect or Comparatively safer than others and $31.82 \%$ preferred Unani medicine to allopathic medicine.

Conclusion: The awareness level regarding Unani medicine was good but the attitude toward and practice of Unani medicine was relatively low. There is a need and scope for health education and promotion to improve the attitude about Unani medicine.

Keywords: AYUSH, Unani, Arogya Fair 


\section{Introduction}

The Unani system of medicine is one of the comprehensive medical systems in India. It provides, preventive, curative, and rehabilitative healthcare. It was introduced to India about a thousand years ago and became indigenous to the country. Having gained recognition from the World Health Organization (WHO) in 1976 as an alternative system to cater the health care needs of human population, wider acceptability is ensured. India leads in the world in education, research and healthcare in Unani System of Medicine. ${ }^{1}$

For the promotion of Unani medicine, many Health Melas, AYUSH cultural programs, community talks providing health tips, public health lectures and free health check-up/OutPatient Departments (OPDs) are organized as community outreach programs by the Central Council for Research in Unani Medicine, Ministry of AYUSH, Govt of India. Health promotion is the process of enabling people to increase control over their health and its determinants and hereby improve their health. Disease aspect is concerned with avoiding disease and involves health promotion behaviour that prevents disease and improves the overall quality of life. The use of alternative medicine in India is rising because of its affordability and accessibility and rise in awareness about the adverse effects of chemicals and drugs prescribed in allopathic medicines. Unani Medicine is one of the widely practiced comprehensive systems of medicine which apart from treating disease endorse prevention of disease and promotion of existing health through holistic approach for a healthy way of living. WHO has launched the traditional medicine strategy 2014-2023 to mainstream the traditional medicine along with allopathic system of medicine because population in rural areas mainly rely on it for their basic health care needs. ${ }^{2,3}$

The AROGYA Fair is a one of its kind events held almost every year, to create awareness on common healthcare issues in India, encourage students to learn preventive healthcare strategies and providing a platform to promote health using infotainment. The Ministry of Ayurveda, Yoga \& Naturopathy, Unani, Siddha and Homoeopathy (AYUSH), Government of India as per its mandate of generating awareness amongst the masses about the strengths of AYUSH systems, has been organising health melas called AROGYA, a Comprehensive Exhibition on these systems, since 2001 . One such health mela was conducted during Arogya Fair 2017 in Visakhapatnam, large number of people visited mela and apart from free medical check-up, mela showcases activities across categories such as health education seminar, entertainment programmes, lifestyle exhibitions, lectures, workshops and competitions.

The present study was carried out to assess the awareness and practices about the Unani system of medicine among population during National 'Arogya Fair' 2017, Visakhapatnam, Andhra Pradesh.

\section{Materials and Methods}

A cross sectional, observational descriptive survey on perception about Unani medicine was conducted on visitors attending the free health check-up clinic at CCRUM stall during National 'Arogya Fair' 2017 held during 8th to $11^{\text {th }}$ September, 2017 at Andhra University ground, Visakhapatnam, Andhra Pradesh, organised by Progress Harmony Development (PHD) Chamber of Commerce and Industry in collaboration with Ministry of AYUSH, Govt. of India and State Govt. of Andhra Pradesh.

A self-administered structured questionnaire was developed for data collection during the fair. The questionnaire was in English and was short and simple comprising 17 items with appropriate options which included multiple choice and close-ended questions. The data collection took only 3 to 5 minutes to complete which was segmented into two sections; the first section consisted of nine questions asking individual's demographic details viz. name, age, gender, marital and educational status, occupation, family income, religion, and residence and the second section consisted eight questions focusing individuals' perception and practice of Unani medicine.

The questionnaires were distributed among the visitors (general population, exhibitors and students) attending the health check-up clinics and the objectives were duly explained to each and every participant and doubts, if any, were clarified. The respondents were informed verbally about the purpose of the study and their verbal consent was taken to participate in the survey. Subsequently, a self-administered structured questionnaire was given to fill it up. The reliability of the questionnaire was calculated using the Cronbach's alpha and a value of 0.755 was found, which is indicative of good reliability. Inclusion criteria for the survey included all patients and visitors of either sex with age more than 18 years attending the health check-up clinics of CCRUM stall during Arogya Health Mela 2017.

\section{Statistical Analysis}

After collection of data it was double entered in Microsoft Excel Sheet and validated. A clean database was generated and analysed in SPSS (version 23). Data was presented by using frequency tables. To find out the association between categorical variables Chi-square test was used. $p$-value less than 0.05 was considered as statistically significant.

\section{Ethical Issues}

Permission was obtained from then Director General of the Central Council for Research in Unani Medicine and participants were assured of the confidentiality of the details collected. 


\section{Result}

\section{Socio-Demographic Data}

The demographic details of participants are summarized in Table 1.Among 1149 respondents, 60.05\% were males and $39.95 \%$ were females with male to female ratio of $3: 2$; the mean age of respondents was $36.78 \pm 10.33$ years ranged from 18 to 82 , the majority (51.87\%) of them were in the age group ranged between $31-45$ years. Overall, $76.94 \%$ of all respondents reported they were married, $20.80 \%$ were single and a small percentage of $2.26 \%$ reported being divorced/ separated or widowed at the time of survey. The survey also shows that large majority (74\%) of the respondents were Hindu, nearly $19.84 \%$ were Muslims, $4.79 \%$ were Christians, $1.31 \%$ were Sikhs, while those following other religion were only less than $0.09 \%$. Education is one of the most important variables of survey that might affect the person's attitudes and the way of understanding the perception towards health. Most of the individuals were educated, literacy level of the respondents was reasonably good with $7.40 \%$ having professional or honours degree, $46.13 \%$ of the respondents were educated up to graduates or post-graduate level, and $25.94 \%$ of the respondents were educated up to intermediate or post high school diploma. Whereas, $11.66 \%$ of the respondents were educated up to high school certificate, and merely $5.05 \%$ of them were illiterate. Of the total respondents, the number of respondents engaged in professional services as well as semi-professional services was $28.63 \%$ and $22.45 \%$ respectively. Similarly, $17.58 \%$ of the respondents were clerical and shop owners, $10.79 \%$ of the respondents were skilled worker, $3 \%$ were semiskilled and $1.57 \%$ were unskilled workers. While near about $16 \%$ were unemployed during the survey. A large majority of the respondents (74.67\%) were belonged to urban area and very few were from metropolitan (5.13\%) and rural area (7.31\%). The majority of the patients $(41.43 \%)$ belonged to lower middle-class socio-economic status (mean $\pm S D, 16.11 \pm 7.64$ ).

Table I: Socio-demographic characteristics of respondents; Arogya, Visakhapatnam ( $=$ I I49)

\begin{tabular}{|c|c|c|}
\hline Variables & Number & Percentage \\
\hline Gender & & \\
\hline Male & 690 & 60.05 \\
\hline Female & 459 & 39.95 \\
\hline Age & & \\
\hline$\leq 30$ & 335 & 29.16 \\
\hline $31-45$ & 596 & 51.87 \\
\hline $46-60$ & 195 & 17.0 \\
\hline$>60$ & 23 & 02.0 \\
\hline Marital Status & & \\
\hline Married & 884 & 76.94 \\
\hline
\end{tabular}

\begin{tabular}{|c|c|c|}
\hline Unmarried & 239 & 20.8 \\
\hline $\begin{array}{l}\text { Widowed/ Divorced/ } \\
\text { Separated }\end{array}$ & 26 & 2.26 \\
\hline \multicolumn{3}{|l|}{ Religion } \\
\hline Hindu & 850 & 74 \\
\hline Muslim & 228 & 19.84 \\
\hline Christians & 55 & 4.79 \\
\hline Sikhs & 15 & 1.31 \\
\hline Others & 1 & 0.09 \\
\hline \multicolumn{3}{|l|}{ Area/ Region } \\
\hline Metropolitan & 59 & 5.13 \\
\hline Urban & 858 & 74.67 \\
\hline Semi urban & 148 & 12.88 \\
\hline Rural & 84 & 7.31 \\
\hline \multicolumn{3}{|l|}{ Education } \\
\hline Illiterate & 58 & 5.05 \\
\hline Primary school certificate & 17 & 1.48 \\
\hline Middle school certificate & 27 & 2.35 \\
\hline High school certificate & 134 & 11.66 \\
\hline $\begin{array}{l}\text { Intermediate/ post high school } \\
\text { diploma }\end{array}$ & 298 & 25.94 \\
\hline Graduate/ Post Graduate & 530 & 46.13 \\
\hline Profession/ honours & 85 & 7.4 \\
\hline \multicolumn{3}{|l|}{ Occupation } \\
\hline unemployed & 184 & 16 \\
\hline unskilled & 18 & 1.57 \\
\hline semi-skilled & 34 & 3 \\
\hline skilled worker & 124 & 10.79 \\
\hline clerical, shop-owner & 202 & 17.58 \\
\hline semi-professional & 258 & 22.45 \\
\hline professional & 329 & 28.63 \\
\hline
\end{tabular}

\section{Perception about Unani Medicine}

To find out the awareness level among respondents this survey was carried out. Of the 1149 participants, $88.42 \%$ ( $n=1016)$ respondents were aware about Unani medicine. There was significant difference in awareness level of the socio-economic group in upper lower-class respondents (Aware: $n=151,79.89 \%$; Not aware: $n=38,20.11 \% ; \chi^{2}=$ $16.08 ; p=0.001)$. The knowledge of the Unani system of medicine was significantly higher in Hindu ( $n=734 ; 86.35 \%$; $\chi 2=13.69)$ and Muslims ( $n=218 ; 95.61 \% ; \chi 2=14.36)$ in comparison to other religions $(p=0.001)$. Similarly, in the elderly ( $\geq 60$ years) people, significant difference was found in the awareness level (Aware: $n=13,56.52 \%$; Not aware: $n=$ 
10, 43.48\%; $\left.\chi^{2}=23.33 ; p=0.001\right)$. Knowledge about Unani seems to be not influenced with education but there is significant association between gender and awareness about Unani system of medicine $(\chi 2=4.391 ; p=0.036)$ (Table 2 ). It was also observed from the survey that $68.5 \%$ of people knew about the existence of Government Unani Hospital/Dispensary near their locality, while $31.5 \%$ have no information about this (Table 3).

\section{Source of Information}

It was noted that almost half ( $n=528,52 \%$ ) of the respondents came to know about Unani medicine from sources such as family, friends and neighbours followed by Internet (13.98\%), television (TV)/radio (11.52\%), newspaper and magazines (11.42\%), brochures, posters and printed material (5.41\%), public lectures/ community health meeting $(4.43 \%)$ and least from the community health workers (1.28\%) (Table 3 ).

Table 2. Relationships between demographics and Unani Medicine awareness

\begin{tabular}{|c|c|c|c|c|c|}
\hline \multirow{3}{*}{ Variable } & & \multicolumn{4}{|c|}{ Awareness about Unani System of Medicine } \\
\hline & \multirow[b]{2}{*}{ N (\%) } & \multicolumn{2}{|c|}{$\mathrm{n}(\%)$} & \multirow[b]{2}{*}{$x^{2}$} & \multirow[b]{2}{*}{ P-value } \\
\hline & & Aware $n=1016(\%)$ & Not Aware $n=133(\%)$ & & \\
\hline \multicolumn{6}{|l|}{ Age } \\
\hline$\leq 30$ & $335(29.16)$ & $300(89.55)$ & $35(10.45)$ & 0.58 & 0.44 \\
\hline $31-45$ & $596(51.87)$ & $538(90.27)$ & $58(9.73)$ & 4.11 & 0.04 \\
\hline $46-60$ & 195 (16.97) & $165(84.62)$ & $30(15.38)$ & 3.33 & 0.06 \\
\hline$>60$ & $23(2.0)$ & $13(56.52)$ & $10(43.48)$ & 23.33 & 0.001 \\
\hline \multicolumn{6}{|l|}{ Gender } \\
\hline Male & $690(60.05)$ & $599(86.81)$ & $91(13.19)$ & \multirow{2}{*}{4.39} & \multirow{2}{*}{0.03} \\
\hline Female & 459 (39.95) & $417(90.85)$ & $42(9.15)$ & & \\
\hline \multicolumn{6}{|l|}{ Socio Economic Status } \\
\hline Lower class & $5(0.44)$ & $3(60)$ & 2(40) & 3.96 & 0.046 \\
\hline Upper lower class & $189(16.45)$ & $151(79.89)$ & $38(20.11)$ & 16.08 & 0.001 \\
\hline Lower middle class & $399(41.43)$ & $362(90.73)$ & $37(9.27)$ & 3.16 & 0.07 \\
\hline upper middle class & $243(14.45)$ & $215(88.48)$ & $28(11.52)$ & 0.001 & 0.97 \\
\hline Upper class & $313(27.24)$ & 285 (91.05) & $28(8.95)$ & 2.90 & 0.08 \\
\hline \multicolumn{6}{|l|}{ Religion } \\
\hline Hindu & $850(73.98)$ & $734(86.35)$ & $116(13.65)$ & 13.69 & 0.001 \\
\hline Muslim & $228(19.84)$ & $218(95.61)$ & $10(4.39)$ & 14.36 & 0.001 \\
\hline Christian & $55(4.79)$ & $48(87.27)$ & $7(12.73)$ & 0.07 & 0.78 \\
\hline Sikh & $15(1.31)$ & $15(100)$ & $0(0.00)$ & 1.99 & 0.15 \\
\hline Others & $1(0.09)$ & $1(100)$ & $0(0.00)$ & 0.13 & 0.71 \\
\hline \multicolumn{6}{|l|}{ Education } \\
\hline Illiterate & $58(5.05)$ & $52(89.66)$ & $6(10.34)$ & 0.09 & 0.76 \\
\hline Primary school certificate & $17(1.48)$ & $13(76.47)$ & $4(23.53)$ & 2.40 & 0.12 \\
\hline Middle school certificate & $27(2.35)$ & $21(77.78)$ & $6(22.22)$ & 3.06 & 0.08 \\
\hline High school certificate & $134(11.66)$ & $120(89.55)$ & $14(10.45)$ & 0.18 & 0.66 \\
\hline $\begin{array}{l}\text { Intermediate/ Post high school } \\
\text { diploma }\end{array}$ & $298(25.94)$ & $266(89.26)$ & $32(10.74)$ & 0.27 & 0.60 \\
\hline Graduate/ Post graduate & 294 (25.59) & $253(86.05)$ & $41(13.95)$ & 2.17 & 0.14 \\
\hline Profession/ Honours & $321(27.94)$ & $291(90.65)$ & $30(9.35)$ & 2.16 & 0.14 \\
\hline
\end{tabular}


Table 3.Perception and practice of Unani system of medicine

\begin{tabular}{|c|c|c|}
\hline Responses of Questions & Frequency & Percentage \\
\hline \multicolumn{3}{|l|}{ Have you heard about Unani System of Medicine? $(n=1149)$} \\
\hline Yes & 1016 & 88.42 \\
\hline \multicolumn{3}{|l|}{ If yes, what was the source of information? $(n=1016)$} \\
\hline Internet & 142 & 13.98 \\
\hline TV/ Radio & 117 & 11.52 \\
\hline Newspaper \& Magazines & 116 & 11.42 \\
\hline Brochures, posters \& other printed materials & 55 & 5.41 \\
\hline Family, Friends, Neighbours & 528 & 52 \\
\hline Public lectures, Community meeting & 45 & 4.43 \\
\hline Outreach programme/ Community health worker visiting home & 13 & 1.28 \\
\hline \multicolumn{3}{|l|}{ When you fall ill, whom you consult first for treatment $(n=1149)$} \\
\hline Allopathic & 480 & 41.78 \\
\hline Ayurveda & 283 & 25 \\
\hline Unani & 224 & 19.5 \\
\hline Homeopathy & 108 & 9.40 \\
\hline Others & 54 & 4.70 \\
\hline \multicolumn{3}{|l|}{ Whether Unani is your first line of treatment? $(n=1149)$} \\
\hline Yes & 224 & 19.50 \\
\hline \multicolumn{3}{|l|}{ Have you taken Unani medicines/treatment earlier ( $n=1149)$} \\
\hline Yes & 480 & 41.78 \\
\hline \multicolumn{3}{|l|}{ What was your experience with Unani treatment? $(n=480)$} \\
\hline Got cured & 175 & 36.46 \\
\hline Very much satisfied & 159 & 33.13 \\
\hline Satisfied & 110 & 22.92 \\
\hline No effect & 15 & 3.13 \\
\hline Worsened & 10 & 2.08 \\
\hline Unanswered & 11 & 2.29 \\
\hline \multicolumn{3}{|l|}{$\begin{array}{l}\text { Do you think that Unani treatment could be a better healthcare option? } \\
\qquad(n=480)\end{array}$} \\
\hline Yes & 444 & 92.50 \\
\hline \multicolumn{3}{|l|}{ If yes, why? ( $n=444)$} \\
\hline Negligible side effects & 310 & 69.82 \\
\hline Affordable & 49 & 11.04 \\
\hline Effective & 41 & 9.23 \\
\hline Palatable & 25 & 5.63 \\
\hline Cure from root cause & 19 & 4.28 \\
\hline \multicolumn{3}{|l|}{$\begin{array}{l}\text { Do you know about any Govt. Unani hospital/ dispensary nearby? } \\
\qquad(n=1016)\end{array}$} \\
\hline Yes & 696 & 68.50 \\
\hline
\end{tabular}


Table 4. Relationships between demographics and response in people who took Unani Medicine

\begin{tabular}{|c|c|c|c|c|c|}
\hline Variable & n (\%) & $\begin{array}{c}\text { Respondents who } \\
\text { took Unani drug } \\
n=480(\%)\end{array}$ & $\begin{array}{c}\text { Others } \\
n=669(\%)\end{array}$ & $x^{2}$ & p-value \\
\hline \multicolumn{6}{|l|}{ Socio Economic Status } \\
\hline Lower class & $5(0.44)$ & $1(20)$ & $4(80)$ & 0.97 & 0.32 \\
\hline Upper lower class & $189(16.45)$ & $70(37.04)$ & $119(62.96)$ & 2.08 & 0.14 \\
\hline Lower middle class & $399(41.43)$ & $178(44.61)$ & $221(55.39)$ & 2.02 & 0.15 \\
\hline upper middle class & $243(14.45)$ & $108(44.44)$ & $135(55.56)$ & 0.90 & 0.34 \\
\hline Upper class & $313(27.24)$ & $123(39.30)$ & $190(60.70)$ & 1.08 & 0.29 \\
\hline \multicolumn{6}{|l|}{ Religion } \\
\hline Hindu & $850(73.98)$ & $337(39.65)$ & $513(60.35)$ & 6.08 & 0.01 \\
\hline Muslim & $228(19.84)$ & $111(48.68)$ & $117(51.32)$ & 5.58 & 0.02 \\
\hline Christian & $55(4.79)$ & $20(36.36)$ & $35(63.64)$ & 0.69 & 0.40 \\
\hline Sikh & $15(1.31)$ & $12(80)$ & $3(20)$ & 9.13 & 0.003 \\
\hline Others & $1(0.09)$ & $0(0.00)$ & $1(100)$ & 0.71 & 0.39 \\
\hline \multicolumn{6}{|l|}{ Age } \\
\hline$\leq 30$ & $335(29.16)$ & $173(51.64)$ & $162(48.36)$ & 18.92 & 0.001 \\
\hline $31-45$ & $596(51.87)$ & $233(39.08)$ & $363(60.91)$ & 3.66 & 0.056 \\
\hline $46-60$ & $195(16.97)$ & $68(34.87)$ & $127(65.13)$ & 4.60 & 0.03 \\
\hline$>60$ & $23(2.0)$ & $6(26.09)$ & $17(73.91)$ & 2.37 & 0.12 \\
\hline \multicolumn{6}{|l|}{ Gender } \\
\hline Male & $690(60.05)$ & $283(41.01)$ & 407 (58.99) & \multirow{2}{*}{0.41} & \multirow{2}{*}{0.52} \\
\hline Female & $459(39.95)$ & $197(42.92)$ & $262(57.08)$ & & \\
\hline \multicolumn{6}{|l|}{ Education } \\
\hline Illiterate & $58(5.05)$ & $18(31.03)$ & $40(68.97)$ & 2.89 & 0.08 \\
\hline Primary school certificate & $17(1.48)$ & $3(17.65)$ & $14(82.35)$ & 4.13 & 0.04 \\
\hline Middle school certificate & $27(2.35)$ & $13(48.15)$ & $14(51.85)$ & 0.46 & 0.49 \\
\hline High school certificate & $134(11.66)$ & $70(52.24)$ & $64(47.76)$ & 6.83 & 0.009 \\
\hline Intermediate/Post high school diploma & $298(25.94)$ & $132(44.30)$ & $166(55.70)$ & 1.050 & 0.30 \\
\hline Graduate/Post graduate & $294(25.59)$ & $119(40.48)$ & $175(59.52)$ & 0.27 & 0.60 \\
\hline Profession/Honours & $321(27.94)$ & $125(38.94)$ & $196(61.06)$ & 1.47 & 0.22 \\
\hline
\end{tabular}

\section{Past Experience with Unani Treatment}

Response of patients who took Unani for any ailment, there was no relation of awareness among respondents who took Unani treatment in the past in respect to gender and socioeconomic status; however, in Hindu and Muslims there was significant difference among respondents who took Unani $(x 2=6.08 ; p=0.01)$ and those who didn't take Unani medicine $(\chi 2=5.58 ; p$-value $=0.02)$. There was significant difference in all age groups except people who were elderly, above 60 years of age and age group 31-45. There was statistically significant difference in the education level of respondents with primary school certificate $(\chi 2=4.130 ; p=0.04)$ and high school certificate $(x 2=6.83 ; p=0.009)$ (Table 4$)$. It is evident that when respondents who took Unani treatment earlier when asked about the past experience, most of the respondents $36.45 \%$ got cured, $33.13 \%$ respondent were very much satisfied and $22.92 \%$ respondent were satisfied with the Unani treatment. However, very few of the respondents have stated worse experience $(2.08 \%)$ or no effect (3.13\%) after the Unani therapy. There were also few $(11,2.29 \%)$ respondents who preferred not to answer the question (Table 3 ). 


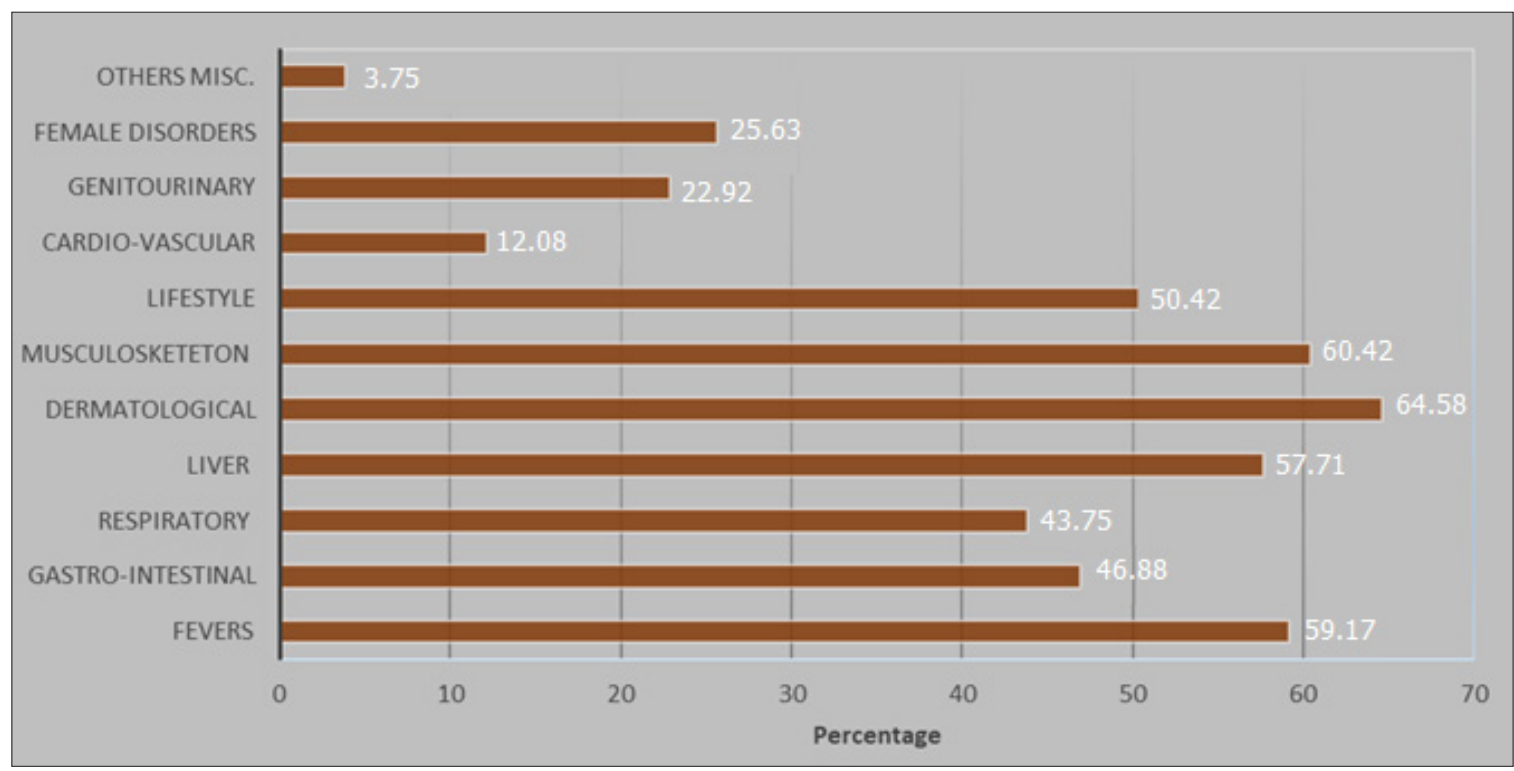

Figure I.Diseases in which respondents preferred Unani Treatment

\section{Attitude towards Unani System of Medicine}

In the survey, when respondents were asked that why do you think Unani was better alternative treatment of choice for treating diseases, majority of the respondents $69.82 \%$ believed that the Unani medicines were comparatively safer and had no or negligible side effects, $11.04 \%$ believed it was cost-effective, $9.23 \%$ respondents thought it was an effective treatment method, $5.63 \%$ believed it was palatable, $4.28 \%$ believed that it is an approach of treating the root cause of the diseases [Table 3].

\section{Medication Use}

Among the surveyed respondents, $41.78 \%$ of the them preferred Unani Medication in the past for number of diseases such as dermatological disorders specially vitiligo and eczema (64.58\%), musculoskeletal disorders (60.42\%), liver disorders (57.71\%), and lifestyle disorders such as diabetes, hypertension, obesity $(50.42 \%)$ and also in gastrointestinal (46.88\%), respiratory problems (43.75\%), female disorders (25.63\%), Genitourinary (22.92\%), fevers (59.17\%) mostly for chikungunya and cardiac (12.08\%) diseases. (Figure 1). However, on enquiring whether Unani Medicine is their preferred method of treatment, 19.5\% of them responded positively.

\section{Discussion}

This survey was conducted on a large sample of people who visited CCRUM stall in the Arogya Fair to examine their knowledge, attitudes, practice and behaviours toward Unani medication use. The age group of 31-45 years formed the largest proportion of the study respondents. This is consistent with many other studies done earlier. ${ }^{4-6}$

The usage of AYUSH across country varies; it was reported to be $32.1 \%$ in Andhra Pradesh according to the National
Sample Survey Organization database by Srinivasan et $a l^{7}$ The awareness level of respondents in the present study was very good which is in consistent with the study done in Dhaka but the majority of the respondents were from a particular sect of religion who are generally inclined towards Unani medicine. ${ }^{4}$ However, less usage of Unani medicine among half of the respondents in present study was attributed to lack of knowledge, perception that it is slow acting so can't be used in emergency conditions, accessibility issues and for some people lack of scientific basis. These findings are consistent with a study conducted among doctors in Mandya district who felt that AYUSH medicines need more scientific testing. ${ }^{5}$

In a study conducted by National Sample Survey Organization's Report covering all parts of Indian subcontinent, less than $30 \%$ of the respondents have reported using AYUSH, the study finds a regional pattern in the usage of different types of traditional medicine in the country, the use of ISM (Ayurveda, Siddha and Unani) across states was high in Tamil Nadu (96.1\%), Gujrat (95\%), Himachal Pradesh (93.8\%), Kashmir (93.7\%), Andhra Pradesh (93\%) and low in West Bengal (20.7\%), Tripura (33.7\%), Arunachal Pradesh (39\%), Jharkhand (49.6\%). ${ }^{7}$

The majority of the respondents reported that they had received knowledge about the system through the 'word of mouth' from their friends, family members, neighbours and colleagues. These findings are consistent with other studies conducted earlier but on small sample size. ${ }^{5-9}$ The outreach activity, medical fraternity, print or social media are not the major sources of information and advice to the people about the Unani system of medicine. Therefore, there is need to improve the awareness about the Unani medicine. 
This present study reported that majority of the respondent have heard of Unani medicine and of which half of the respondents $(41.78 \%)$ reported that they had Unani medicines in the past for various problems which is actually less if we compare a study conducted on 300 subjects which came out to be $74 \%$ (Imran et $a /){ }^{8}$

When the respondents were asked about the preferred mode of treatment, the findings revealed that Allopathic medicine was the most preferred mode of treatment in majority of the respondents (41.78\%) which is consistent with earlier study in which $72.88 \%$ of the consumers preferred Allopathic medicines over traditional medicine. ${ }^{10}$ Albeit, there were few $(n=224,19.5 \%)$ respondents in whom Unani medicine was preferred choice over Allopathic Medicine. The respondents later asked question regarding the use of Unani medicine as a better healthcare option, out of 480 , majority 444 (92.5\%) of them responded positively by giving reasons that it has no or negligible side effects (69.82\%), effective (9.23\%), affordable (11.04\%), being convenient palatable (5.63\%) and cure diseases from its root (4.28\%). 5,7 These findings are comparable with another study in which $62.8 \%$ respondents thought it has no side effects, ${ }^{8}$ but in terms of affordability which came out to be $(11.04 \%)$ in present study is much less in contrast to many other study findings done previously on traditional medicine in Nigeria, Ethiopia. ${ }^{11-13} \mathrm{~A}$ study from Dhaka observed that people are turning to Unani due to serious side effects of modern medicine and lack of effectiveness in many of the chronic disorders.

The outcome of the Unani treatment in these respondents ( $n=480 ; 41.78 \%$ ) was quite satisfactory, $36.46 \%$ got cured completely and $33.13 \%$ were very much satisfied only a small number had either no effect (3.13\%) or their disease get worsened (2.08\%).

Unani medicine from study was majorly used in the present study for the treatment of skin diseases specially Vitiligo (64.58\%), joint problems; osteo-arthritis, rheumatoid arthritis, Sciatica, Gout, ankylosis spondylitis, cervical spondylitis (60.42\%), Gastro-intestinal disorders (46.88\%), liver disorders; Jaundice, Hepatitis (57.71\%), lifestyle disorders; Obesity, Hypertension, Diabetes mellitus (50.42\%), various fevers (59.17\%); chikungunya, Typhoid, Malaria, viral etc. Other diseases for which the respondents use herbal medicine are in Figure 1.

Majority $68.50 \%$ of the respondents knew that Unani medical facility is available in their vicinity as evident by the information present on the Website, of the total 1039 dispensaries, 196 Unani dispensaries and one Unani Medical College. ${ }^{14}$

\section{Acknowledgment}

We are grateful to then DG I/c, CCRUM Dr. Anil Khurana for guidance and permission.

\section{Conflicts of Interest: None \\ References}

1. Unani Medicine In India - An Overview, New Delhi: Govt. of India, Ministry of Health and Family Welfare, Min. of AYUSH publication; 2016.

2. Carlin C. Traditional Healing: Modern medicine's friend or foe. The Guardian.

3. Mir IA, Jahan N, Sofi G, Mehfooz S, Husain M. Role of Unani System of Medicine in Global Health Care: An Emerging Field. Orthopedic \& Muscular System 2017; 6(4). DOI: 10.4172/2161-0533.1000249

4. Siddika R, Nyeem M, Nowrose M, Meher, Mannan, MA. Awareness on Unani medicine among the urban community people in Dhaka city. International Journal of Advanced Educational Research 2017; 2(3): 66-71

5. Shashikumar BM, Sheethal MP. Knowledge, Attitude And Practices Regarding AYUSH Among The Allopathic Doctors In Mandya District. Natl J Integr Res Med 2015; 6 (4): 68-71.

6. Gari A, Yarlagadda R, Wolde-Mariam M. Knowledge, attitude, practice, and management of traditional medicine among people of Burka Jato Kebele, West Ethiopia. J Pharm Bioallied Sci 2015; 7(2): 136-144. DOI:10.4103/0975-7406.148782:10.4103/09757406.148782.

7. Srinivasan R, Sugumar VR. Spread of Traditional Medicines in India: Results of National Sample Survey Organization's Perception Survey on Use of AYUSH. Journal of Evidence-Based Complementary \& Alternative Medicine 2017; 22(2): 194-204. https:// doi.org/10.1177/2156587215607673.

8. Imran M, Amir M, Naqvi H, Naaz S. The prevalence and patterns of usage of Ayurveda, Unani and home remedies in younger adults of rural North India. International Journal of Green Pharmacy 2017; 11 (2): 108.

9. Wani P, Siddiqui MJ, Zaheer MT, Ahmad S. A study to assess the knowledge attitude and practices of the Unani Medicine in the new comers of A \& U Tibbia College. Elixir Human Physio 2014; (66): 20700-704.

10. Katole H. Reasons of Customer Preference towards Allopathy versus Ayurvedic therapy. International Journal of Research in Pharmaceutical Sciences 2020. Avaliable from: https://pharmascope.org/ijrps/article/ view/ 1941/3250\#citations.

11. Singh P, Yadav RJ, Pandey A. Utilization of indigenous 
systems of medicine \& homoeopathy in India. Indian J Med Res 2005; 122(2): 137-142.

12. Giday M, Asfaw Z, Woldu Z, Teklehaymonot T. Medicinal plant knowledge of the Bench ethnic group of Ethiopia: an ethnobotanical investigation. J Ethnobiology Ethnomedicine 2009; 5: 34. Avaliable from: https:// doi.org/10.1186/1746-4269-5-34.

13. Bamidele JO, Adebimpe WO, Oladele EA. Knowledge, attitude and use of alternative medical therapy amongst urban residents of Osun State, southwestern Nigeria. Afr J Tradit Complement Altern Med 2009; 6(3): 281288. Published 2009 May 7. DOI:10.4314/ajtcam. v6i3.57175.

14. AYUSH Department [cited 15 June 2020]. Available from: http://ayushdepthyd.nic.in/index.html. 